\title{
Pengaruh reciprocal teaching terhadap kemampuan pemecahan masalah matematis ditinjau dari self-efficacy siswa
}

\author{
Melinda Chusnul Chotima ${ }^{1^{*}}$ (D), Yusuf Hartono ${ }^{2}$, Nila Kesumawati ${ }^{1}$ \\ ${ }^{1}$ Program Studi Pendidikan Matematika, Universitas PGRI Palembang, Indonesia \\ 2 Program Studi Pendidikan Matematika, Universitas Sriwijaya, Indonesia \\ *Corresponding Author. E-mail: MelindaChusnulChotima20@gmail.com
}

\begin{tabular}{ll}
\hline \multicolumn{1}{c}{ ARTICLE INFO } & \multicolumn{1}{c}{ ABSTRACT } \\
\hline Article History: & Penelitian ini bertujuan untuk mendeskripsikan pengaruh model Reciprocal Teaching terhadap \\
Received: 13 Dec. 2018 & kemampuan pemecahan masalah matematis yang ditinjau dari self-efficacy siswa kelas VIII di \\
Revised: 15 May 2019 & SMP PGRI 11 Palembang. Penelitian ini menggunakan metode eksperimen dengan populasi \\
Accepted: 28 June 2019 & siswa kelas VII. Teknik pengambilan sampel yang dilakukan adalah simple random sampling. \\
& Sampel penelitian adalah kelas VII.1 yang diberi perlakuan berupa pembelajaran menggunakan \\
& model Reciprocal Teaching dan kelas VII.2 yang diberi perlakuan berupa pembelajaran \\
Keywords: & konvensional. Teknik pengumpulan data menggunakan posttest untuk mengukur kemam- \\
Reciprocal teaching & puan pemecahan masalah matematis siswa dan angket untuk mengukur self-efficacy siswa. \\
Pemecahan masalah & Teknik analisis data yang digunakan adalah ANOVA dua jalur pada taraf signifikansi 5\% ( $\alpha=$ \\
Self-efficacy & 0,05). Hasil penelitian menunjukkan bahwa terdapat perbedaan signifikan kemampuan \\
Problem-solving & pemecahan masalah matematis siswa antara kelas yang mendapat perlakuan berupa model \\
& Reciprocal Teaching dan kelas dengan pembelajaran konvensional. Terdapat perbedaan \\
& signifikan kemampuan pemecahan masalah matematis siswa ditinjau dari self-efficacy siswa, \\
& namun tidak terdapat pengaruh interaksi antara pembelajaran dan self-efficacy terhadap \\
& kemampuan pemecahan masalah matematis siswa kelas VII di SMP PGRI 11 Palembang.
\end{tabular}

This research aimed to describe the effect of the Reciprocal Teaching model on mathematical problem-solving abilities in terms of the self-efficacy of seventh-grade students at SMP PGRI 11 Palembang, Indonesia. This research used an experimental method with a population was all seventh-grade students. The sampling technique used was simple random sampling. The research sample was class VII.1 which was treated in the form of learning using the Reciprocal Teaching model and class VII.2 which was treated in the form of expository learning. The data collection techniques used were a posttest to measure students' mathematical problem-solving abilities and questionnaires to measure students' self-efficacy. The data analysis technique used was two-way ANOVA at a significance level of $5 \%(\alpha=0.05)$. The results showed that there was a significant difference in students' mathematical problem-solving abilities between the class that was treated in the form of Reciprocal Teaching models and class with conventional learning. There was a significant difference in students' mathematical problem-solving abilities in terms of students' self-efficacy, but there was no effect of interaction between learning and self-efficacy on the mathematical problem-solving abilities of seventh-grade students at SMP PGRI 11 Palembang.

\section{SCAN ME}

This is an open access article under the CC-BY-SA license

\section{How to Cite:}

Chotima, M. C., Hartono, Y., \& Kesumawati, N. (2019). Pengaruh reciprocal teaching terhadap kemampuan pemecahan masalah matematis ditinjau dari self-efficacy siswa. PYTHAGORAS: Jurnal Pendidikan Matematika, 14(1), 71-79. doi: https://doi.org/10.21831/pg.v14i1.22375 


\section{PENDAHULUAN}

Saat ini peserta didik masih banyak yang menganggap bahwa mata pelajaran matematika itu sulit, sehingga banyak peserta didik yang mudah menyerah saat pendidik memberi suatu permasalahan-permasalahan matematika yang berbeda dengan contoh yang diberikan atau sedikit lebih rumit (Novferma, 2016; Utami \& Wutsqa, 2017). Suatu soal atau pertanyaan merupakan suatu masalah apabila soal atau pertanyaan tersebut menantang untuk diselesaikan atau dijawab, dan prosedur untuk menyelesaikannya atau menjawabnya tidak dapat dilakukan secara rutin (Febriyanti \& Irawan, 2017). Berdasarkan pernyataan tersebut setiap pertanyaan atau masalah hendaknya merangsang kemampuan kognitif peserta didik untuk menganalisis dan memahami suatu pertanyaan atau masalah, serta dapat mengoptimalkan kemampuan berpikirnya, sehingga mampu menemukan jawaban yang tepat. Proses menjawab tersebut akan membuat peserta didik mampu memecahkan suatu permasalahan matematis. Dalam proses pembelajaran matematika pasti akan memiliki suatu tujuan yang telah ditetapkan, salah satu tujuan pembelajarannya adalah dapat atau mampu memecahkan masalah matematis.

Pembelajaran matematika seharusnya diarahkan pada kegiatan yang mendorong para peserta didik untuk belajar lebih aktif di kelas (Apino \& Retnawati, 2017) dan dapat meningkatkan rasa ingin tahu (Bukhori, 2018; Widiastuti \& Santoso, 2014) serta meningkatkan kemampuan pemecahan masalah matematis peserta didik dalam pembelajaran matematika (Bottge, 2001; NCTM, 2000; Osman, Che Yang, Abu, Ismail, Jambari, \& Kumar, 2018) . Proses untuk mengembangkan suatu kemampuan pemecahan masalah matematis dapat dilakukan melalui latihan berpikir secara matematis agar peserta didik dapat menggunakan dalam kehidupan sehari-hari serta dibarengi dengan rasa keyakinan dari dalam diri melalui proses pemecahan masalah sehingga peserta didik memiliki kesiapan dalam menghadapi tantangan dalam hidupnya. Untuk mengetahui kemampuan pemecahan masalah siswa mengacu pada beberapa indikator penilaian.

Menurut Kesumawati (2010) indikator yang menunjukkan kemampuan pemecahan masalah matematis meliputi beberapa hal. Pertama, menunjukkan pemahaman masalah, meliputi kemampuan mengidentifikasi unsur-unsur yang diketahui, ditanyakan, dan kecukupan unsur yang diperlukan. Kedua, mampu membuat/ menyusun model matematika, meliputi kemampuan masalah situasi sehari-hari dalam matematika. Ketiga, memilih dan mengembangkan strategi pemecahan, meliputi kemampuan memunculkan berbagai kemungkinan atau pengetahuan mana yang dapat digunakan dalam pemecahan masalah tersebut. Keempat, mampu menjelaskan dan memeriksa kebenaran jawaban yang diperoleh. Adapun indikator pemecahan masalah matematis menurut Febriyanti dan Irawan (2017) meliputi (1) siswa dapat menunjukkan pemahaman masalah yang terdapat pada soal, (2) siswa dapat memilih pendekatan dan metode pemecahan masalah secara tepat, dan (3) siswa dapat menyelesaikan permasalahan tersebut secara tepat.

Berdasarkan beberapa pendapat yang telah dikemukakan, maka dapat disimpulkan bahwa setidaknya terdapat empat indikator kemampuan pemecahan masalah matematis yaitu (1) menunjukkan pemahaman masalah, meliputi kemampuan mengidentifikasi unsur-unsur yang diketahui, ditanyakan, dan kecukupan unsur yang diperlukan, (2) mampu membuat/menyusun model matematika, meliputi kemampuan masalah situasi sehari-hari dalam matematika, (3) memilih dan mengembangkan strategi pemecahan masalah, dan (4) mampu menjelaskan dan memeriksa kebenaran jawaban yang diperoleh.

Salah satu faktor yang mempengaruhi kemampuan pemecahan masalah matematis siswa adalah self-efficacy (Novferma, 2016; Utami \& Wutsqa, 2017). Self-efficacy merupakan suatu keyakinan yang harus dimiliki siswa agar berhasil dalam proses pembelajaran. Self-efficacy adalah suatu pendapat atau keyakinan yang dimiliki oleh seseorang mengerti kemampuannya dalam menampilkan suatu bentuk perilaku dan hal ini berhubungan dengan situasi yang dihadapi oleh seseorang tersebut (Bandura, 2009; Zubaidah \& Risnawati, 2016). Dengan demikian, selfefficacy merupakan suatu keyakinan akan kemampuan yang dimiliki seorang peserta didik tersebut. Keyakinan diri (self-efficacy) merupakan salah satu aspek yang memberikan pengaruh terhadap keberhasilan peserta didik dalam menyelesaikan pertanyaan-pertanyaan pemecahan masalah dengan baik (Liu \& Koirala, 2009; Lunenberg, 2011). Keterkaitannya dengan pemecahan masalah, self-efficacy memiliki fungsi sebagai alat untuk menilai suatu keberhasilan siswa dalam menyelesaikan soal-soal pemecahan masalah.

Untuk mengetahui tingkat keyakinan diri (self-efficacy) siswa dan untuk mengetahui tingkat kemampuan pemecahan masalah matematis siswa diambil model pembelajaran Reciprocal Teaching. Model pembelajaran Reciprocal Teaching adalah suatu model pembelajaran yang mengharuskan satu atau beberapa siswa untuk menyajikan suatu materi kedepan kelas (Noorlaili \& Kusumawati, 2013). Karakteristik dari model pembelajaran 
Reciprocal Teaching yaitu siswa menjadi guru dengan menerapkan 4 strategi, diantaranya: bertanya (question generating), memprediksi (predicting), menjelaskan (clarifiying), dan merangkum (summarizing) (Muslimin, Indaryanti, \& Susanti, 2017). Jadi model pembelajaran Reciprocal Teaching merupakan salah satu model pembelajaran yang menuntut siswa menjadi lebih aktif dan percaya diri, karena dalam model pembelajaran ini siswa akan belajar sendiri materi yang diberikan oleh pendidik dan peserta didik akan menyampaikan temuan yang dipelajari kepada temannya.

Menurut Muslimin et al. (2017) karakteristik dari model pembelajaran Reciprocal Teaching yaitu siswa menjadi "guru" dengan menerapkan empat strategi, yaitu bertanya (question generating), memprediksi (predicting), menjelaskan (clarifiying), dan merangkum (summarizing). Menurut Awaliah dan Idris (2015) pada pembelajaran terbalik (Reciprocal Teaching) siswa diajarkan empat strategi pembelajaran yaitu: (1) siswa mempelajari dan merangkum materi yang diberikan oleh guru; (2) siswa membuat pertanyaan yang berkaitan dengan materi yang dipelajari, apabila dia tidak mampu memecahkan sendiri kemudian diajukan pada pengajar; (3) siswa harus mampu menjelaskan kembali isi materi yang dipelajarinya kepada rekannya; dan (4) siswa dapat memprediksi kemungkinan pengembangan materi yang dipelajarinya saat itu. Dengan diterapkannya model Reciprocal Teaching dalam pembelajaran matematika, diharapkan dapat meningkatkan kemampuan pemecahan masalah matematis siswa.

Berdasarkan latar belakang masalah dan kajian teori yang telah dikemukakan sebelumnya, dapat dipahami bahwa model Reciprocal Teaching dan self-efficacy merupakan variabel penting yang diduga berpengaruh terhadap kemampuan pemecahan masalah matematis siswa. Dengan demikian tujuan penelitian ini adalah untuk mendeskripsikan pengaruh model Reciprocal Teaching terhadap kemampuan pemecahan masalah matematis siswa ditinjau dari self-efficacy. Adapun tujuan khusus dari penelitian ini yaitu: (1) mendeskripsikan perbedaan kemampuan pemecahan masalah matematis siswa antara kelompok yang mendapat perlakuan berupa pembelajaran dengan model Reciprocal Teaching dan kelompok kontrol; (2) mendeskripsikan perbedaan kemampuan pemecahan masalah matematis siswa ditinjau dariself-efficacy; dan (3) mendeskripsikan pengaruh interaksi antara model pembelajaran dan self-efficacy terhadap kemampuan pemecahan masalah matematis siswa.

\section{METODE}

Penelitian ini menggunakan metode eksperimen dengan rancangan penelitian menggunakan postest-only control design (Arikunto, 2014). Penelitian ini dilaksanakan di kelas VII SMP PGRI 11 Palembang pada tahun pelajaran 2018/2019 semester ganjil, yang beralamatkan JI. Sapta Marga, Bukit Sangkal, Kecamatan Kalidoni, Kota Palembang, Sumatra Selatan. Sampel dalam penelitian bersifat homogen atau memiliki kemampuan yang sama. Adapun teknik yang digunakan dalam pengambilan sampel yaitu dengan menggunakan teknik simple random sampling atau pengambilan sampel secara acak. Dua kelas dari kelas VII, yaitu kelas VII.1 dan VII.2 terpilih sebagai kelas sampel, dimana satu kelas sebagai kelas eksperimen dan kelas lain sebagai kelas kontrol.

Proses penelitian dimulai dengan memberikan angket kepada seluruh siswa yang dijadikan sampel yaitu kelas VII.1 dan VII. 2 yang bertujuan untuk mengukur tinggi, sedang, dan rendahnya tingkat self-efficacy siswa. Dilanjutkan dengan memberi perlakuan berupa pembelajaran selama 3 kali pertemuan. Perlakuan pada kelas eksperimen menggunakan model pembelajaran Reciprocal Teaching dan pada kelas kontrol menggunakan pembelajaran konvensional (ekspositori). Selanjutnya memberikan tes akhir (posttest) untuk mengukur kemampuan pemecahan masalah matematis siswa di kelas eksperimen maupun di kelas kontrol.

Instrumen penelitian yang digunakan adalah tes pemecahan masalah matematika dan angket self-efficacy. Tes digunakan untuk mengukur kemampuan pemecahan masalah matematis siswa yang diberikan di akhir pertemuan setelah siswa diberi perlakuan baik di kelas eksperimen (pembelajaran dengan model Reciprocal Teaching) maupun di kelas kontrol (pembelajaran ekspositori). Sebelum digunakan, instrumen tes divalidasi terlebih dahulu dengan meminta penilaian dan masukan dari ahli (expert judgement). Ahli yang dimaksud yaitu dosen pendidikan matematika di Universitas PGRI Palembang. Perbaikan instrumen dilakukan berdasarkan masukan ahli dan instrumen digunakan setelah ahli menyatakan bahwa instrumen telah valid dan layak digunakan. Instrumen angket penelitian menggunakan angket dari Somakim (2010) terdiri atas 25 butir pernyataan yang diajukan kepada siswa untuk mengumpulkan data tentang self-efficacy siswa. Pernyataan yang ada dalam angket merupakan pernyataan positif dan negatif. Angket yang digunakan disusun berdasarkan skala Likert.

Pertanyaan penelitian yang akan dijawab dalam penelitian ini meliputi (1) apakah terdapat perbedaan kemampuan pemecahan masalah matematis antara siswa yang belajar dengan model Reciprocal Teaching dan 
siswa yang belajar dengan pembelajaran ekspositori; (2) apakah terdapat perbedaan kemampuan pemecahan masalah matematis siswa ditinjau dari tingkat self-efficacy; dan (3) apakah terdapat pengaruh interaksi antara model pembelajaran yang digunakan (Reciprocal Teaching vs. ekspositori) dan self-efficacy siswa terhadap kemampuan pemecahan masalah matematis siswa. Untuk menjawab pertanyaan penelitian tersebut dilakukan uji hipotesis dengan menggunakan teknik analisis data ANOVA dua jalur. Semua pengujian hipotesis dalam penelitian ini dilakukan pada taraf signifikan $5 \%(\alpha=0.05)$ Sebelum uji hipotesis, terlebih dahulu dilakukan uji prasyarat data yaitu: uji normalitas dan uji homogenitas. Semua uji hipotesis dan uji prasyarat dilakukan dengan bantuan program SPSS.

\section{HASIL DAN PEMBAHASAN}

Penelitian ini dilakukan untuk mendeskripsikan pengaruh model Reciprocal Teaching terhadap kemampuan pemecahan matematis siswa ditinjau dari self-efficacy. Sebagaimana telah dikemukakan pada bagian metode, akan ada tiga hipotesis utama yang akan diuji dalam penelitian ini. Sesuai dengan tujuan tersebut, analisis data dalam penelitian ini dilakukan menggunakan ANOVA dua jalur. Setelah data diperoleh dan ditabulasi oleh peneliti, terlebih dahulu dilakukan uji prasyarat data yang meliputi uji normalitas data dan uji kesamaan varians (homogenitas) kedua kelompok perlakuan (eksperimen vs. kontrol)

Uji normalitas dilakukan menggunakan data kemampuan pemecahan masalah yang diperoleh baik di kelas eksperimen maupun di kelas kontrol. Uji yang digunakan untuk perhitungan pada uji normalitas data yaitu Kolmogorov-Smirnov Test. Adapun hasil uji normalitas data pada kelas eksperimen dan kelas kontrol disajikan pada Tabel 1.

Tabel 1. Uji Normalitas Data

\begin{tabular}{llll}
\hline & \multicolumn{3}{l}{ Kolmogorov-Smirnov } \\
\cline { 2 - 4 } & Statistic & df & Sig. \\
\hline Kelas Eksperimen & 0,150 & 32 & 0,067 \\
\hline Kelas Kontrol & 0,138 & 32 & 0,129 \\
\hline
\end{tabular}

Dari Tabel 1 dapat dilihat pada uji Kolmogorov-Smirnov diketahui bahwa nilai signifikansi untuk kelas eksperimen yaitu 0.067 dan kelas kontrol yaitu 0,129. Karena nilai signifikansi untuk kelas eksperimen dan kelas kontrol lebih dari 0,05 , maka hal ini menunjukkan bahwa data kemampuan pemecahan masalah matematis siswa ini berasal dari populasi yang berdistribusi normal.

Uji homogenitas dilakukan untuk membuktikan apakah sampel yang diambil berasal dari populasi yang homogen. Perhitungan uji homogenitas pada penelitian ini menggunakan uji Lavene Statistics dan hasilnya disajikan pada Tabel 2.

Tabel 2. Hasil Uji Kesamaan Varians Kelas Eksperimen dan Kontrol

\begin{tabular}{llll}
\hline \multicolumn{4}{l}{ Variabel: Kemampuan pemecahan masalah } \\
\hline Levene Statistic & $\mathrm{df1}$ & $\mathrm{df2}$ & Sig. \\
\hline 0,224 & 1 & 62 & 0,638 \\
\hline
\end{tabular}

Dari hasil Tabel 2 diketahui bahwa nilai signifikansi sebesar 0,638. Karena nilai signifikansi lebih dari 0,05, maka dapat disimpulkan bahwa kelas eksperimen dan kelas kontrol mempunyai varian sama (homogen).

Setelah uji prasyarat terpenuhi, dimana data berdistribusi normal dan kedua kelompok memiliki varians yang sama (homogen), selanjutnya akan dilakukan uji hipotesis menggunakan ANOVA dua jalur. Hasil uji ANOVA dua jalur terhadap data kemampuan pemecahan masalah kelas eksperimen dan kelas kontrol disajikan pada Tabel 3. Pada Tabel 3 dapat dilihat bahwa nilai signifikansi untuk sumber keragaman MODEL yaitu sebesar 0,020 (kurang dari 0,05$)$, sehingga cukup alasan untuk menolak $H_{0}$. Dengan demikian dapat disimpulkan bahwa terdapat perbedaan kemampuan pemecahan masalah yang signifikan antara kelas dengan model pembelajaran Reciprocal Teaching dan kelas dengan pembelajaran ekspositori. Hal tersebut dapat juga dimaknai bahwa model pembelajaran Reciprocal Teaching memberikan pengaruh terhadap kemampuan pemecahan masalah matematis siswa kelas VII SMP PGRI 11 Palembang, dimana rata-rata skor yang diperoleh pada kelas tersebut lebih tinggi dibandingkan rata-rata skor pada kelas kontrol. 
PYTHAGORAS: Jurnal Pendidikan Matematika, 14 (1), 2019 - 75

Melinda Chusnul Chotima, Yusuf Hartono, Nila Kesumawati

Tabel 3. Hasil Uji ANOVA Dua Jalur

\begin{tabular}{llllll}
\hline Source & Type III Sum of Squares & df & Mean Square & $F$ & Sig. \\
\hline Corrected Model & 5682,572 & 5 & 1136,514 & 6,819 & 0,000 \\
Intercept & 126300,338 & 1 & 126300,338 & 757,825 & 0,000 \\
SE & 4550,539 & 2 & 2275,269 & 13,652 & 0,000 \\
MODEL & 958,266 & 1 & 958,266 & 5,750 & 0,020 \\
SE ${ }^{*}$ MODEL & 60,851 & 2 & 30,425 & 0,183 & 0,834 \\
Error & 9666,374 & 58 & 166,662 & & \\
Total & 276000,038 & 64 & & & \\
Corrected Total & 15348,946 & 63 & & & \\
\hline
\end{tabular}

Pada Tabel 3, untuk sumber keragaman SE diperoleh nilai signifikansi sebesar 0,000 (kurang dari 0,05), sehingga cukup bukti untuk menolak $H_{0}$. Dengan demikian dapat disimpulkan bahwa terdapat perbedaan yang signifikan kemampuan pemecahan masalah matematis siswa ditinjau dari tingkat self-efficacy (tinggi, sedang, rendah) siswa kelas VII SMP PGRI 11 Palembang. Untuk mendeskripsikan perbedaan tersebut, maka pengujian statistik dilanjutkan dengan uji Tukey dan hasilnya disajikan pada Tabel 4.

Tabel 4. Uji Perbandingan Kemampuan Pemecahan Masalah Ditinjau dari Self-Efficacy

\begin{tabular}{lllllll}
\hline \multirow{2}{*}{$\begin{array}{l}\text { (I) Self-Efficacy } \\
\text { SE Tinggi }\end{array}$} & (J) Self-Efficacy & $\begin{array}{l}\text { Mean Difference } \\
(I-J)\end{array}$ & Std. Error & Sig. & \multicolumn{2}{c}{ 95\% Confidence Interval } \\
\cline { 7 - 8 } & SE Sedang & $16,27^{*}$ & 3,362 & 0,000 & 8,18 & 24,36 \\
& SE Rendah & $15,76^{*}$ & 6,251 & 0,038 & 0,72 & 30,80 \\
\hline \multirow{2}{*}{ SE Sedang } & SE Tinggi & $-16,27^{*}$ & 3,362 & 0,000 & $-24,36$ & $-8,18$ \\
& SE Rendah & $-0,51$ & 6,236 & 0,996 & $-15,51$ & 14,49 \\
\hline SE Rendah & SE Tinggi & $-15,76^{*}$ & 6,251 & 0,038 & $-30,80$ & $-0,72$ \\
& SE Sedang & 0,51 & 6,236 & 0,996 & $-14,49$ & 15,51 \\
\hline
\end{tabular}

Berdasarkan Tabel 4 dapat dilihat bahwa kemampuan pemecahan masalah siswa yang memiliki self-efficacy tinggi berbeda signifikan dengan siswa yang memiliki self-efficacy sedang $($ sig. $=0,000)$ dengan selisih rata-rata kemampuannya yaitu sebesar 16,27 poin. Kemampuan pemecahan masalah siswa yang memiliki self-efficacy tinggi juga berbeda signifikan dengan siswa yang memiliki self-efficacy rendah (sig. $=0,038$ ) dengan selisih rata-rata kemampuannya sebesar 15,76 poin. Sedangkan kemampuan pemecahan masalah siswa yang memiliki self-efficacy sedang tidak berbeda signifikan dengan siswa yang memiliki self-efficacy rendah (sig. $=0.096$ ) dengan selisih ratarata kemampuannya hanya sebesar $-0,51$ poin.

Hasil penelitian juga menujukkan bahwa tidak ada pengaruh interaksi antara model pembelajaran (Reciprocal Teaching vs. ekspositori) dan self-efficacy (tinggi, sedang, rendah). Hal ini dapat dilihat pada Tabel 3 dimana nilai signifikansi untuk sumber keragaman SE*Model yaitu sebesar 0,834 (lebih dari 0,05), sehingga tidak cukup bukti untuk menolak $H_{0}$. Hal tersebut menunjukkan bahwa tidak terdapat pengaruh interaksi antara model pembelajaran (Reciprocal Teaching vs. ekspositori) dan self-efficacy (tinggi, sedang, rendah) terhadap kemampuan pemecahan masalah matematis siswa kelas VII SMP PGRI 11 Palembang. Secara grafis, tidak adanya pengaruh yang signifikan interaksi antar model dan self-efficacy terhadap kemampuan pemecahan masalah matematis siswa dapat dilihat pada Gambar 1.

Berdasarkan Gambar 1, terlihat bahwa ditinjau dari semua tingkatan self-efficacy, rata-rata kemampuan siswa pada kelas yang mendapat perlakuan berupa pembelajaran dengan model Reciprocal Teaching selalu di atas ratarata kemampuan siswa yang mendapat pembelajaran konvensional. Hal ini jelas mengindikasikan bahwa interaksi antara model pembelajaran dan tingkat self-efficacy siswa tidak memberikan pengaruh apa-apa terhadap kemampuan pemecahan masalah matematis siswa. Dalam hal ini yang memberikan efek terhadap kemampuan pemecahan masalah matematis siswa hanyalah perbedaan perlakuan atau perbedaan tingkat self-efficacy siswa itu sendiri. 


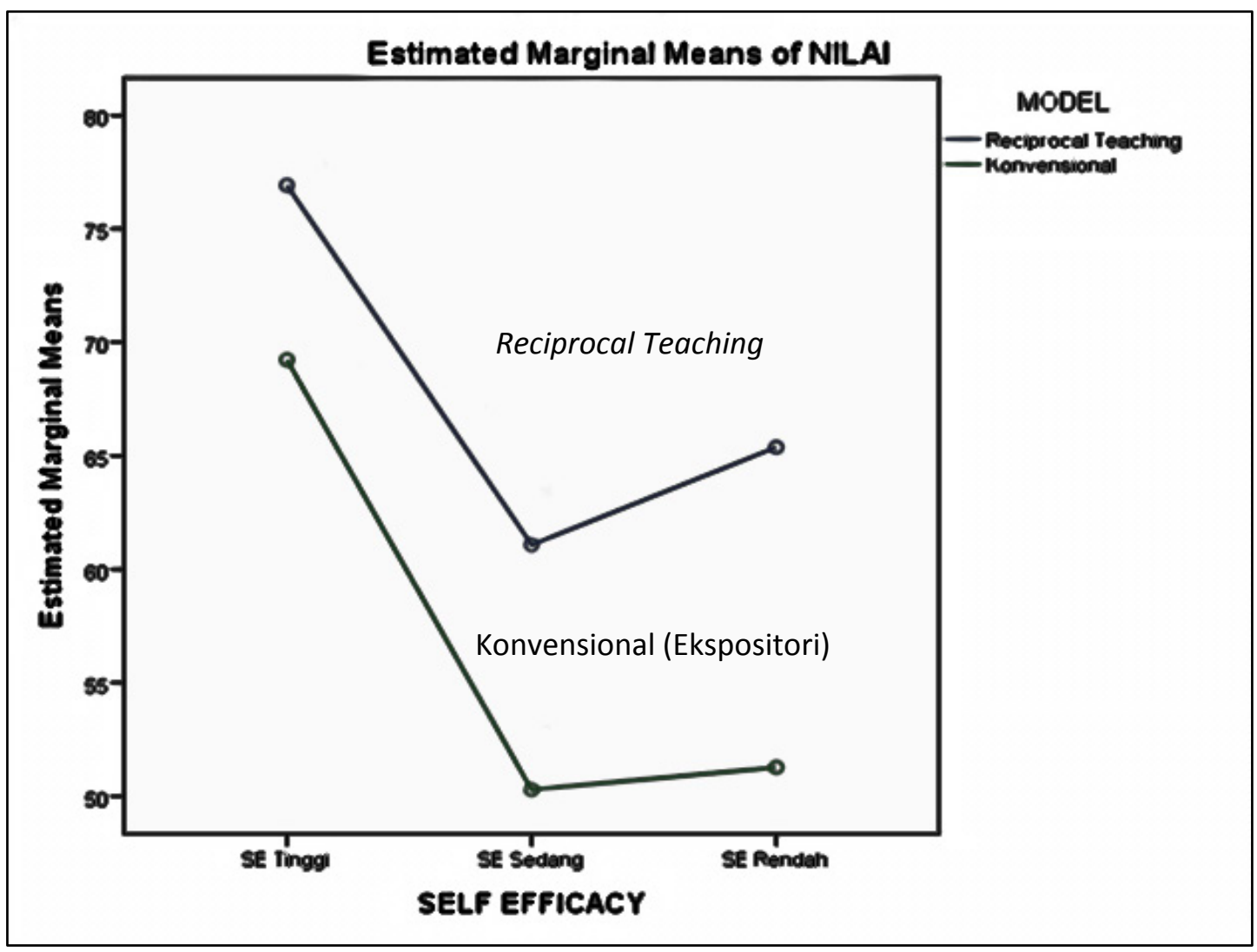

Gambar 1. Pola Interaksi Model Pembelajaran dan Self-Efficacy

Pada Gambar 1, juga dapat dilihat bahwa siswa yang memiliki self-efficacy tinggi cenderung memiliki kemampuan pemecahan masalah yang tinggi pula. Hal ini menunjukkan bahwa self-efficacy juga memberikan efek signifikan terhadap kemampuan pemecahan masalah matematis siswa. Untuk itu menjadi penting bagi guru untuk meningkatkan self-efficacy siswa dalam rangka meningkatkan kemampuan pemecahan masalahnya. Namun yang menarik adalah bahwa siswa yang memiliki self-efficacy rendah kemampuan pemecahan masalah matematisnya lebih baik dari pada siswa yang memiliki self-efficacy sedang (lihat Gambar 1). Perbedaan yang sangat mencolok yaitu terjadi pada kelas yang mendapat perlakuan berupa pembelajaran dengan model Reciprocal Teaching, dimana selisih rata-rata kemampuannya secara grafis terpaut cukup jauh. Hal ini tentunya menjadi temuan unik, dan dapat dijadikan masukan bagi para guru dan peneliti untuk menyelidiki kembali fenomena tersebut.

\section{Pembahasan}

Hasil penelitian menunjukkan bahwa pada kelompok eksperimen yang diberi perlakuan dengan model pembelajaran Reciprocal Teaching memiliki rata-rata skor akhir yang lebih tinggi dibandingkan dengan rata-rata kelompok kontrol yang diberi perlakuan dengan pembelajaran konvensional. Dari hasil perhitungan dengan menggunakan ANOVA dua jalur maka disimpulkan bahwa ada pengaruh model pembelajaran Reciprocal Teaching terhadap kemampuan pemecahan masalah matematis siswa di SMP PGRI 11 Palembang. Hasil penelitian ini sejalan dengan hasil penelitian sebelumnya, diantaranya yang dilakukan oleh Awaliah dan Idris (2015) dimana hasil penelitiannya penelitiannya menunjukkan bahwa terdapat pengaruh yang signifikan pada hasil belajar matematika antara siswa yang diajar dengan menggunakan model Reciprocal Teaching dan siswa yang diajar dengan tidak menggunakan model Reciprocal Teaching pada siswa kelas VIII MTsN Balang-balang Kecamatan Bontomarannu Kabupaten Gowa.

Temuan dalam penelitian ini juga memperkuat hasil penelitian Jatisunda (2017) yang menyelidiki hubungan self-efficacy siswa SMP dengan kemampuan pemecahan masalah matematis. Hasil penelitian tersebut yaitu terdapat hubungan yang positif antara kemampuan pemecahan masalah matematis dan sel-efficacy matematis siswa. Hubungan tersebut masuk dalam kategori sedang, artinya hubungan antara kemampuan pemecahan masalah dan self-efficacy berada di tengah. Hubungan ini menunjukkan hubungan yang tidak begitu baik, juga tidak begitu jelek. Hasil penelitian Moma (2014) juga sejalan dengan hasil penelitian ini, dimana peningkatan self-efficacy 
matematis siswa yang memperoleh pembelajaran generatif lebih baik dari pada siswa yang memperoleh pembelajaran konvensional.

Penelitian-penelitian sebelumnya, seperti Argikas dan Khuzaini (2016) melaporkan bahwa dengan menggunakan model pembelajaran reciprocal teaching dapat meningkatkan pemahaman konsep matematika siswa, dibandingkan dengan pembelajaran secara konvensional. Selain itu, Fitri (2017) juga melaporkan bahwa terdapat perbedaan skor self-efficacy antara siswa yang belajar menggunakan modul matematika dengan siswa yang memperoleh pembelajaran konvensional. Dari kedua hasil penelitian tersebut dan ditambah dengan temuan dalam penelitian ini, semakin memperkuat bahwa model Reciprocal Teaching dan self-efficacy siswa perlu mendapat perhatian bagi guru, terutama dalam upaya untuk meningkatkan kemampuan pemecahan masalah matematis siswa.

Hasil penelitian yang menunjukkan bahwa tidak adanya pengaruh interaksi antara model pembelajaran dan self-efficacy tidak sejalan dengan hasil penelitian yang telah dilakukan oleh Erwanto, Maryatmi, dan Budiyanto (2018). Dengan demikian, kemampuan, penelitian ini menunjukkan bahwa kemampuan pemecahan masalah matematis siswa tidak selalu dipengaruhi oleh interaksi antara perlakuan yang diberikan dengan tingkat selfefficacy siswa. Hasil penelitian Novferma (2016) menunjukkan bahwa meskipun siswa telah memiliki self-efficacy yang tinggi, tetapi sebagian besar siswa masih kesulitan dalam memecahkan masalah matematika. Dengan demikian, dapat dipahami bahwa tidak selalu self-efficacy memberikan efek positif terhadap peningkatan kemampuan pemecahan masalah siswa.

Temuan menarik lainnya dalam penelitian ini yaitu adanya fakta bahwa siswa yang memiliki self-efficacy rendah memiliki kemampuan pemecahan masalah yang lebih baik dibandingkan dengan siswa yang memiliki selfefficacy sedang. Hal ini sejalan dengan temuan penelitian Utami dan Wutsqa (2017), dimana dalam penelitian tersebut ditemukan bahwa hubungan antara self-efficacy dan kemampuan pemecahan masalah siswa sangat rendah, sehingga sangat mungkin ketika siswa memiliki self-efficacy rendah memiliki kemampuan lebih baik dibandingkan dengan siswa yang memiliki self-efficacy sedang. Hal tersebut diduga disebabkan karena siswa yang self-efficacy-nya sedang cenderung ragu-ragu dalam menyelesaikan soal yang diberikan. Hal ini sejalan dengan pendapat Novferma (2016) yang menjelaskan bahwa faktor-faktor yang menyebabkan siswa kesulitan dalam menyelesaikan masalah yaitu siswa kurang teliti, siswa sering merasa cemas, siswa mudah menyerah, dan tergesagesa dalam mengerjakan soal. Faktor-faktor tersebut tentunya sangat berkaitan dengan self-efficacy yang dimiliki siswa, sehingga sangat berdampak terhadap kemampuan siswa dalam menyelesaikan masalah matematika.

\section{SIMPULAN}

Berdasarkan hasil penelitian dan pembahasan, maka dapat dikemukakan beberapa kesimpulan. Pertama, terdapat pengaruh model Reciprocal Teaching terhadap kemampuan pemecahan masalah matematis siswa kelas VII di SMP PGRI 11 Palembang. Kedua, terdapat perbedaan kemampuan pemecahan masalah matematis siswa ditinjau dari self-efficacy siswa kelas VII di SMP PGRI 11 Palembang. Ketiga, tidak terdapat pengaruh interaksi antara pembelajaran (Reciprocal Teaching dan ekspositori) dan self-efficacy terhadap kemampuan pemecahan masalah matematis siswa kelas VII di SMP PGRI 11 Palembang.

Berdasarkan kesimpulan penelitian ini, maka dapat disampaikan beberapa saran. Pertama, menggunakan model pembelajaran Reciprocal Teaching membutuhkan waktu yang sedikit lebih lama, jadi untuk peneliti lain diharapkan bisa memanfaatkan waktu semaksimal mungkin dan bisa mengkondisikan para siswa yang kurang memperhatikan temannya yang berperan sebagai guru. Kedua, untuk penelitian selanjutnya diharapkan mencoba model pembelajaran Reciprocal Teaching pada jenjang yang berbeda. Ketiga, pembelajaran dengan model pembelajaran Reciprocal Teaching ini dapat dijadikan sebagai salah satu alternatif model pembelajaran yang dapat diterapkan di sekolah, sehingga dapat meningkatkan kemampuan pemecahan masalah matematis siswa. Dalam melaksanakan proses pembelajaran matematika, hendaknya guru juga memberikan beberapa masalah yang membuat siswa mengaitkan hubungan konsep-konsep matematika yang telah dimiliki, sehingga kemampuan pemecahan masalah yang dimiliki siswa semakin baik. Keempat, disarankan untuk peneliti lain agar melakukan penelitian lanjutan dengan melibatkan variabel moderator lainnya, seperti kemampuan awal, kecerdasan intelektual, motivasi belajar siswa, hasil belajar, gaya berpikir, dan lain sebagainya. Selain itu dapat juga dilakukan penelitian dengan mengukur kemampuan (variabel terikat) berbeda, misalnya kemampuan komunikasi, kemampuan pemahaman konsep, kemampuan penalaran, berpikir kritis dan kreatif. Di samping itu, disarankan juga untuk 
melibatkan sampel penelitian yang lebih besar, menggunakan rancangan eksperimen yang lebih kompleks dan waktu pelaksanaan lebih lama.

\section{DAFTAR PUSTAKA}

Apino, E., \& Retnawati, H. (2017). Developing instructional design to improve mathematical higher order thinking skills of students. Journal of Physics: Conference Series, 812(1). 1-7. doi: https://doi.org/10.1088/17426596/812/1/012100

Arikunto, S. (2014). Prosedur penelitian: Suatu pendekatan praktik. Jakarta: Rineka Cipta

Argikas, T. B., \& Khuzaini, N. (2016). The application of reciprocal teaching method for improving the understanding of mathematics concept of 7th grade students SMP Negeri 2 Depok. Jurnal Mercumatika: Jurnal Penelitian Matematika dan Pendidikan Matematika, 1(1), 67-79. doi: http://dx.doi.org/10.26486/mercumatika.v1i1.186

Awaliah, R., \& Idris, R. (2015). Pengaruh penggunaan model reciprocal teaching terhadap hasil belajar matematika siswa kelas VIII MTsN Balang-Balang Kecamatan Bontomarannu Kabupaten Gowa. MaPan: Jurnal Matematika dan Pembelajaran, 3(1), 59-72. doi: https://doi.org/10.24252/mapan.2015v3n1a6

Bandura, A. (2009). Self-efficacy in changing societies. Cambridge, UK: Cambridge University press.

Bottge, B. A. (2001). Reconceptualizing mathematics problem solving for low-achieving students. Remedial and Special Education, 22(2), 102-112. doi: https://doi.org/10.1177/074193250102200204

Bukhori, B. (2018). Pengembangan perangkat pembelajaran dengan pendekatan PBL berorientasi pada penalaran matematis dan rasa ingin tahu. Pythagoras: Jurnal Pendidikan Matematika, 13(2), 133-147. doi: https://doi.org/10.21831/pg.v13i2.21169

Erwanto, E., Maryatmi, A., \& Budiyanto, A. (2018). The effects of reciprocal teaching learning strategy and selfefficacy on learning outcomes of early childhood (AUD) mathematical logic. Al-Jabar: Jurnal Pendidikan Matematika, 9(1), 41-50. doi: https://doi.org/10.24042/ajpm.v9i1.2567

Febriyanti, C., \& Irawan, I. (2017). Meningkatkan kemampuan pemecahan masalah dengan pembelajaran matematika realistik. Delta-Pi: Jurnal Matematika dan Pendidikan Matematika, 6(3), 31-41. Retrieved from https://ejournal.unkhair.ac.id/index.php/deltapi/article/view/350

Fitri, I. (2017). Peningkatan self-efficacy terhadap matematika dengan menggunakan modul matematika kelas VIII SMP Negeri 2 Bangkinang. Journal Cendekia: Jurnal Pendidikan Matematika, 1(2), 25-34. doi: https://doi.org/10.31004/cendekia.v1i2.17

Jatisunda, M. G. (2017). Hubungan self-efficacy siswa SMP dengan kemampuan pemecahan masalah matematis. Jurnal Theorems (The Original Research of Mathematics), 1(2), 24-30. Retrieved from https://jurnal.unma.ac.id/index.php/th/article/view/375

Kesumawati, N. (2010). Peningkatan kemampuan pemahaman, pemecahan masalah, dan disposisi matematis siswa SMP melalui pendekatan pendidikan matematika realistik. (Unpublished Doctoral dissertation). Universitas Pendidikan Indonesia, Bandung.

Liu, X. \& Koirala, H. (2009). The effect of mathematics self-efficacy on mathematics achievement of high school students. NER Conference Proceedings, 30. Retrieved from: https://opencommons.uconn.edu/nera_2009

Lunenburg, F. C.(2011).Self-efficacy in the workplace: implication for motivation and performance. International Journal of Management, Bussissnes, and Administration, 14(1),1-6. Retrieved from http://www.nationalforum.com/Journals/IJMBA/IJMBA.htm

Moma, L. (2014). Peningkatan self-efficacy matematis siswa SMP melalui pembelajaran generatif. Jurnal Cakrawala Pendidikan, 33(3), 434-444. doi: https://doi.org/10.21831/cp.v3i3.2387

Muslimin, M., Indaryanti, I., \& Susanti, E. (2017). Pembelajaran matematika dengan model reciprocal teaching untuk melatih kecakapan akademik siswa kelas VIII SMP. Jurnal Pendidikan Matematika, 11(1), 1-14. doi: https://doi.org/10.22342/jpm.11.1.4682.1-14 
PYTHAGORAS: Jurnal Pendidikan Matematika, 14 (1), 2019 - 79

Melinda Chusnul Chotima, Yusuf Hartono, Nila Kesumawati

NCTM. (2000). Principles and standards for school mathematics. Reston, VA: Author.

Noorlaili, N., \& Kusumawati, E. (2013). Pengaruh model reciprocal teaching terhadap hasil belajar Matematika siswa kelas VII SMP. Edu-Mat: Jurnal Pendidikan Matematika, 1(1), 34-41. doi: http://dx.doi.org/10.20527/edumat.v1i1.553

Novferma, N. (2016). Analisis kesulitan dan self-efficacy siswa SMP dalam pemecahan masalah matematika berbentuk soal cerita. Jurnal Riset Pendidikan Matematika, 3(1), 76-87. doi: https://doi.org/10.21831/jrpm.v3i1.10403

Osman, S., Che Yang, C. N. A., Abu, M. S., Ismail, N., Jambari, H., \& Kumar, J. A. (2018). Enhancing students' mathematical problem-solving skills through bar model visualisation technique. International Electronic Journal of Mathematics Education, 13(3), 273-279. doi: https://doi.org/10.12973/iejme/3919

Somakim, S. (2010). Peningkatan kemampuan berpikir kritis dan self-efficacy matematika sisa SMP dengan penggunaan Pendekatan PMRI (Unpublished doctoral dissertation). Universitas Pendidikan Indonesia, Bandung.

Utami, R. W., \& Wutsqa, D. U. (2017). Analisis kemampuan pemecahan masalah matematika dan self-efficacy siswa SMP negeri di Kabupaten Ciamis. Jurnal Riset Pendidikan Matematika, 4(2), 166-175. doi: https://doi.org/10.21831/jrpm.v4i2.14897

Widiastuti, W., \& Santosa, R. (2014). Pengaruh metode inkuiri terhadap ketercapaian kompetensi dasar, rasa ingin tahu, dan kemampuan penalaran matematis. Pythagoras: Jurnal Pendidikan Matematika, 9(2), 196-204. doi: https://doi.org/10.21831/pg.v9i2.9080

Zubaidah, A., \& Risnawati, R. (2016). Psikologis pembelajaran matematika. Yogyakarta: Aswaja Pressindo. 